\begin{tabular}{|l|l|l||}
\hline \multicolumn{2}{|c|}{ PublisherInfo } \\
\hline \hline PublisherName & $:$ & BioMed Central \\
\hline \hline PublisherLocation & $:$ & London \\
\hline \hline PublisherImprintName & $:$ & BioMed Central \\
\hline \hline
\end{tabular}

\title{
A comprehensive patient information resource
}

\begin{tabular}{|l|l|l||}
\hline \multicolumn{2}{|c||}{ ArticleInfo } \\
\hline \hline ArticleID & $:$ & 3672 \\
\hline \hline ArticleDOI & $:$ & $10.1186 /$ bcr-2000-2-webreport0005 \\
\hline \hline ArticleCitationID & $:$ & 0005 \\
\hline \hline ArticleSequenceNumber & $:$ & 38 \\
\hline \hline ArticleCategory & $:$ & Web Report \\
\hline \hline ArticleFirstPage & $:$ & 1 \\
\hline \hline ArticleLastPage & $:$ & 3 \\
\hline \hline & & RegistrationDate : 2000-2-2 \\
ArticleHistory & $:$ & OnlineDate $\quad$ 2000-2-2 \\
\hline \hline ArticleCopyright & $:$ & Current Science Ltd2000 \\
\hline \hline ArticleGrants & $:$ & \\
\hline \hline ArticleContext & $:$ & 1305822 \\
\hline \hline
\end{tabular}


Aff1 http://spis.co.uk

\section{Overview}

BreastCancer.net is primarily a patient resource, although some sections would be of interest to healthcare workers, researchers or students. The site features daily news updates, a searchable news archive, contact details for US support groups and medical centers, and links to sites relating to all aspects of breast cancer. The site is accredited by the Health on the Net Foundation and the Recreational Software Advisory Council.

\section{Content}

The 'newsroom' contains up-to-the-minute medical news drawn from numerous sources, including Reuters, Eureka, Doctor's Guide, PR Newswire, the AMA, significant medical journals and major US newspapers. The news covers most aspects of the disease, including aetiology, genetics, clinical trial updates, conventional and alternative treatment strategies, cost considerations and outcomes. Breaking news is displayed on the homepage and items over a day old are listed in the archive (all articles since 1997 are stored in a fully searchable database). Users can receive free daily or weekly e-mail notifications of breaking news, new postings, and significant changes to the site. There is a searchable database of breast cancer support groups and medical centers; unfortunately these cover the US only. The 'articles' section contains links to specific pages on external sites: these cover both obvious and offbeat topics, ranging from artistic expression and sexuality to politics and financial help. The 'websites' section is a collection of links to various professional and patient sites, chat forums and cancer victims' personal pages.

\section{Other comments}

The news section is updated several times daily. Other sections have not been updated since around April 1998, and some links have moved or no longer exist.

\section{Evaluation}


This site has many attractions and is an excellent starting point for information on all aspects of breast cancer. The news service is unique in pulling together articles from both scientific and lay publications. The links section goes beyond the usual selection of societies/associations and presents articles and advice on non-clinical topics - such as psychosocial and insurance issues - which are undoubtedly of equal importance to the patient.

\section{References}

1. BreastCancer.net. [http://www.breastcancer.net/] 